\title{
Tax compliance of MSME's taxpayer: Implementation of theory of planned behavior
}

Afuan Fajrian Putra

Faculty of Economics, Universitas Islam Indonesia, Yogyakarta, Indonesia

afuan.putra@uii.ac.id

Amir Hakim bin Osman

Faculty of Accountancy, Universiti Teknologi MARA Perak Branch, Tapab Campus, Malaysia

Follow this and additional works at: https://journal.uii.ac.id/jca

Copyright (C2019 Journal of Contemporary Accounting and Authors.

To cite this article: Afuan Fajrian Putra \& Amir Hakim bin Osman. (2019). Tax compliance of MSME's taxpayer: Implementation of theory of planned behavior. Journal of Contemporary Accounting, 1(1), 1-10. doi:10.20885/jca.vol1.iss1.art1 


\title{
Tax compliance of MSME's taxpayer: Implementation of theory of planned behavior
}

\author{
Afuan Fajrian Putra ${ }^{1}$, Amir Hakim bin Osman ${ }^{2}$ \\ ${ }^{1}$ Faculty of Economics, Universitas Islam Indonesia, Yogyakarta, Indonesia \\ ${ }^{2}$ Faculty of Accountancy, Universiti Teknologi MARA Perak Branch, Tapah Campus, Malaysia
}

JEL Classification:

H24, M48

\section{Keywords:}

Theory of planned behaviour, tax compliance, taxpayer, MSME

\section{Corresponding Author:}

afuan.putra@uii.ac.id

DOI:

10.20885/ica.vol1.iss 1. art 1

Copyright (C) 2019

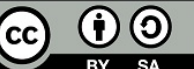

This is an open access under CC-BY-SA license

\begin{abstract}
This research is aimed to examine the factors that influence the compliance behaviour of MSME's taxpayer. The variables refer to the theory of planned behaviour, which are attitude towards behaviour, subjective norms and perceived behavioural control that later its influence will be tested towards compliance behaviour in settling the tax. This research will test those factors simultaneously or partially. This research employed population of entire MSMEs that registered in The Cooperation Agency, Small and Middle Enterprises in Sleman Regency, Indonesia. While, the number of samples are obtained by employing slovin formula, which is 100 respondents that cover eight groups of business sector. Questionnaire is applied as data collection technique that employs data analysis method by applying multiple regression and SPSS version 16 as analysis tools. This research indicates that attitude towards behaviour, subjective norms, and perceived behavioural control, simultaneously and significantly influence the compliance behaviour of MSME's taxpayer. Partially, variable of subjective norms and perceived behavioural control positively influence compliance behaviour of taxpayers in fulfilling their obligation in accomplishing the tax. While the variable of attitude towards behaviour is not positively influence the behaviour of taxpayer's compliance.
\end{abstract}

\section{Introduction}

Tax is one of the important objects for a country, as it is determined as source of revenue at most of the countries. The same thing applies in Indonesia, in which $80 \%$ of state's revenue is originated from tax collected from its citizens. By considering to this vital role of tax, special attention from government is required to maximize the state's earnings from tax. Indonesia government should provide breakthroughs, so the existing programs designated to maximize the tax income could be maintained. Government, in this case, General Directorate of Taxes Republic of Indonesia have made several changes as well as program that could escalate tax income, such as performing tax reformation to eliminate bad perception on corruption in the taxation environment, the alteration of Official Assessment System to Self-Assessment System that provides full authorization to taxpayer in performing self-calculation, self-payment and self-reporting. Besides, in 2016, there was Tax amnesty program that provided absolution over tax interest and fine. The latest program in 2018 was the reduction of final income tax (PPh) for MSME actors initially $1 \%$ over the omzet to $0,5 \%$. These programs are designed to improve maximum income from tax as target, since in the last couple years Indonesia dealt with issues regarding to state's income from tax. It can be seen from the last 9 years; the government could not achieve the target that already set earlier (detikFinance, 2017).

There are numbers of sectors that could be utilized or optimized by the government related to tax income. One of the sectors that potentially could contribute to tax income is MSME, that overally could contribute to Brutto Domestic Product (PDB) as 60,34\% for the last 5 years. The 
figure is increasing from $57,84 \%$. MSME also contributes to workers utilization, that constantly increase previously from 96,99\% to $97,22 \%$ (CNN Indonesia, 2016). Total MSMEs recorded in Indonesia until December 2017 is 59.697 .827 (Berita Satu, 2018). This indicates that MSMEs provide huge contributions to Indonesian economics and more earnings for tax income from this sector. This potency will be useless if not followed with the awareness from taxpayer to fulfil his obligation to pay. It is not easy to nurture the awareness of taxpayer to obey the taxation obligations. It is caused by awareness of taxpayer towards benefits obtained from paying the tax is inversely proportional against thoughts or perceptions of taxpayer (Budiningrum, 2014; Putra, 2017; Putri, 2014; Rustiyaningsih, 2012; Siahaan, 2013; Yanah, 2013). The tendency of taxpayer to his reluctance in paying the tax is quite high due to perception that tax will reduce the total number of the income. Most of all, the tax management that still likely vulnerable to fraud. The process of calculating the amount of tax, payment process and the anxiety of tax maldistribution or tax being corrupted are the issues of the reluctance. Those are the main factors in doing or not doing certain behaviour under their wish. These factors are in line with the theory brought by Ajzen (1991), which is the Theory of Planned Behaviour (TPB) stated that the final decision is on each individual for doing or not doing certain actions. The theory explains that there are three constructs that could influence a person or an individual in performing or not performing an action, which are attitude towards behaviour, subjective norms and perceived behavioural control.

Perception or point of view of taxpayer about taxes benefit could influence whether a person would like to pay or not. This perception or this point of view will construct the attitude towards behaviour or action, so a person prefers or not prefer to conduct certain action. If a taxpayer has a positive attitude and considers that the payment will provide benefits also for others, then it will motivate the taxpayer to settle the payment. On the contrary, if a taxpayer has negative attitude and bad thoughts about the tax, it will lead to reluctancy to pay. Beside attitude factor, the existence of other persons on the surrounding also plays certain role. A person will pay his tax if his surroundings, for instance family, co-workers, and neighbours motivate a person to settle the tax. On the contrary, if the surroundings do not provide motivation in paying the tax or suggest negative recommendation, then the payment will not be performed. The easiness factor in performing certain action is also deliberated as specific consideration. If a detention existed in performing an action, hence the taxpayer tends to obey. If those detentions are controllable, then the behaviour tends to be executed (Putra \& Basuki, 2015).

Based on the background that was discussed before, hence questions could be revealed, whether attitude towards behaviour, subjective norms and Perceived Behavioural Control positively influence the compliance of taxpayer of MSMEs. Hence, this research is designated to examine the effect of attitude towards behaviour, subjective norms and Perceived Behavioural Control to the compliance of personal taxpayer of MSMEs.

\section{Literature Review and Hypothesis Development}

\section{Theory of Planned Behaviour (TPB)}

TPB is a theory that functioned to predict one's intention in performing certain action (Hartono, 2008). TPB is a development of previous theory, which is TRA that predicts a behaviour that could be controlled completely by an individual. While, TPB is designated to predict a behaviour that partially be controlled by a person (Putra \& Basuki, 2015). Not all behaviour could be controlled by an individual due to the possibilities of obstacles or difficulties in performing the action (Hartono, 2008). Hence, in TPB, additional construct is added, called as perceived behavioural control. Behaviour of an individual could be caused by three factors, which are attitude towards behaviour, subjective norms, perceived behavioural control that trigger the intention to conduct certain action (Machrus \& Purwono, 2010). Attitude is a form of evaluation of an individual towards his future behaviour. Whereas, subjective norms are defined as social pressures that are 
exposed to individual towards future behaviours. While, perceived behavioural control is form of perception about easiness or difficulties on a future behaviour (Burhanudin, 2015). Based on the research conducted by Bobek et al., (2013) indicates that the theory is capable to explain an intention of a taxpayer in following the taxation regulation. Moreover, Winardi, (2013) as well as Putra and Basuki (2015) applied this theory to explain someone's intention in performing complaint. On the other hand, Putri (2014) employed this theory to predict the compliance of personal taxpayer.

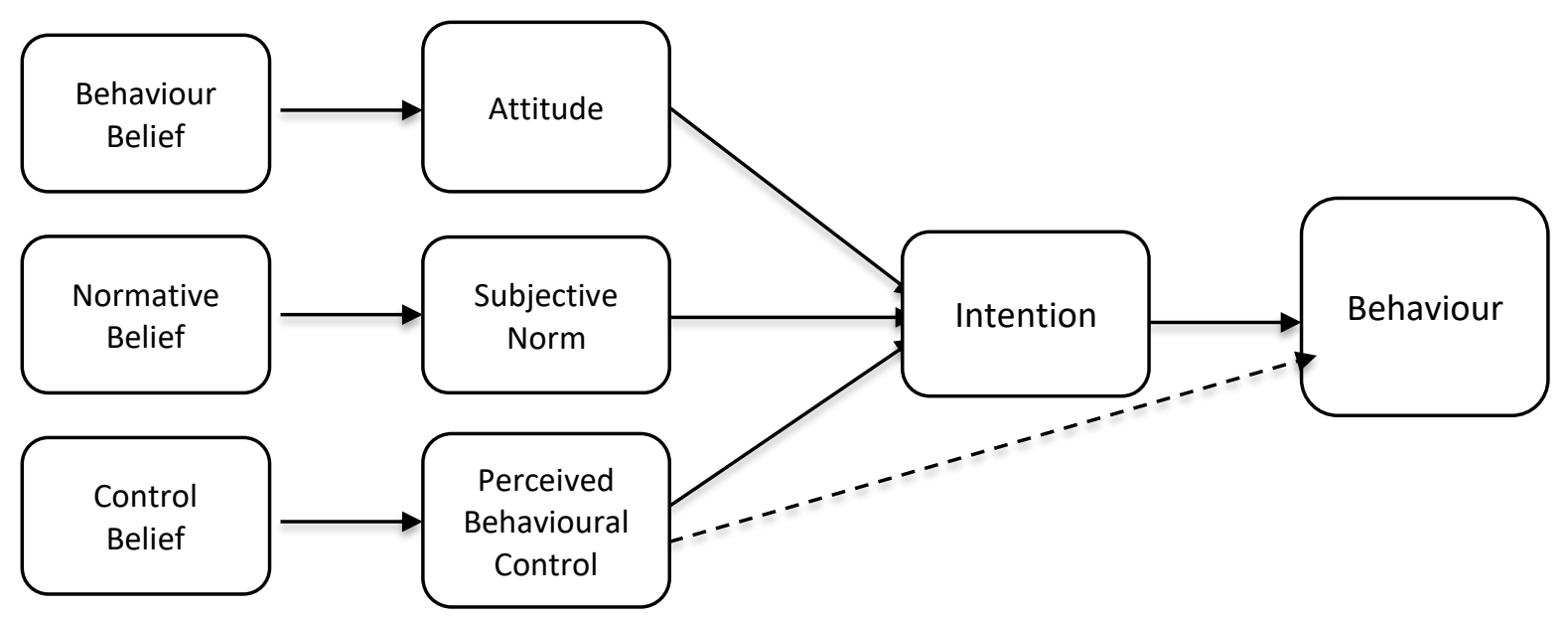

Figure 1. Theory of Planned Behaviour

Source: Ajzen (1991)

\section{The Influence of Attitude Towards Compliance of Taxpayer}

Attitude is defined as perception or point of view of an individual towards a certain behaviour on progress. Ajzen (1991) delivered that attitude is a perspective from an individual towards certain behaviour that assessed by the basic of benefits or loss. Park and Blenkinsopp (2009) stated that attitude is someone's assessment on how a person would approve a certain attitude. This attitude could be interpreted as an evaluation of belief as well as positive and negative affect from an individual if a certain behaviour being conducted (Hartono, 2008). Attitude towards behaviour could be influenced by faith that owned by an individual towards certain future behaviour (Putra \& Basuki, 2015). Besides, Putri (2014) explained that attitude towards behaviour is a part of supporting or taking side sentiment towards certain behaviour, vice versa. In terms of taxation, attitude could be interpreted as positive or negative judgement on the benefits obtained by every individual once he obeyed the taxation regulation. Individual with positive attitude will assume that the tax will have enormous benefits not only for him but for others as well. Individual who has positive attitude towards tax will think that tax will be managed properly by government and be returned back to society through infrastructure, public service and programs that are designed entirely for the purpose of people's welfare. Whereas, the individual with negative attitude will suggest that benefits from tax are small. The individual with negative characteristics thinks that tax has been paid will be unusable since the benefits are less useful. Based on above explanation, it can be formulated a hypothesis, as follows:

H1: Attitude positively influences the compliance behaviour of taxpayer.

\section{The Influence of Subjective Norms Towards Compliance Behaviour of Taxpayer}

Subjective norm is defined as perspective of other person's or person near the individual that may influence the perception of an individual towards behaviour. Ajzen (1991) revealed that subjective norm is suggested as sensed social pressure to perform or not to perform certain behaviour. A 
person will carry out a behaviour that pleases and accepted by his surrounding, such as family, friends, co-workers and superior. On the contrary, a person will ignore the behaviour if there is a rejection or disapproval from surrounding people (Putra \& Basuki, 2015), if every individual believes that the certain behaviour should be avoided, it will create a social pressure to make this behaviour would not be performed (Winardi, 2013). Moreover, Hartono (2008) explained that subjective norm is a form of perception or point of view of an individual towards beliefs originated from others that allows an individual to perform or not to perform a behaviour. Park and Blenkinsopp (2009) stated that subjective norms could be influenced by normative belief as part of individual trust towards future behaviour. That behaviour will be conducted with the consent, approval and acceptance from surroundings. In its relationship with taxation, subjective norm can be a motivation for individual to perform a certain behaviour. For instance, a family that supports each other to settle the tax, in which it could become a good example for other family member. The supports from family are attached to the perception that tax provide big benefits. Based on above explanation, it could be formulated following hypothesis:

H2: Subjective norms positively influence the compliance behaviour of taxpayer.

\section{The Influence of Perceived Behavioural Control Towards Compliance Behaviour of Taxpayer}

Perceived behavioural control could be interpreted as the perception or point of view on the level of easiness or difficulties once an attitude is performed. This perception, which could influence every individual to whether perform or not perform the behaviour. Ajzen (1991) revealed that the level of easiness or difficulties could be the main factor for an individual to conduct a behaviour or not. People tends to perform certain behaviour if it is considered easy to be performed and prefers to pull himself out once the behaviour is difficult to be done (Putra \& Basuki, 2015). Furthermore, the tendency to convert the intention to be real behaviour could be influenced from the existence of obstacles and difficulties as well as potential opportunities in performing the behaviour. This indicates that several behaviours could be uncontrollable due to specific factors, which may affect it (Hartono, 2008). In its correlation with taxation, an individual tends to obey the taxation regulation if he trusts or beliefs that the existing system is considered as easy to execute. This easiness will later influence someone's behaviour to obey the taxation rule. But, if an individual believes that the taxation system is difficult to be performed, hence he tends to have reluctancy in obeying taxation regulation. Based on above explanation, it can be formulated a hypothesis, as follows:

H3: Perceived behavioural control positively influences the compliance behaviour of taxpayer.

\section{Research Method}

\section{Population and Sample}

The population of this research is the entire MSMEs listed in the Agency of Cooperation, Small and Middle Enterprise in Sleman regency, Indonesia. Based on data attached in its website, it is recorded 27.139 MSMEs that are divided into eight business sectors. The determination of sample that will be used in this research uses Slovin formula that resulted 99,63 samples and rounded to 100 samples. Samples cover eight business group, which are culinary, fashion, education, automotive, agrobusiness, information technology, trading and service, and others.

Data source that employed in this research is primary data. It is defined as data that are obtained directly from source without intermediary (Putra \& Basuki, 2015). The data collection techniques apply questionnaire. Questionnaire is described as set of questions that should be answered by the respondents as research objects. Type of scale employed for measuring the variables of the research is interval scale with 4 segment likert scale method. Point 1 represents the 
lowest value stated the statement of strongly disagree, while point 4 indicates the highest score of strongly agree.

\section{Operational Definition}

\section{Attitude towards behaviour}

Attitude is defined as someone's assessment on his approval or rejection towards certain behaviour (Park \& Blenkinsopp, 2009). Attitude is also interpreted as someone's positive or negative judgement towards behaviour (Putra \& Basuki, 2015). This variable is derived from Putra and Basuki (2015) and being measured by using two indicators. First indicator related with belief's assessment towards behaviour (behavioural belief). While, the second indicator related to evaluation on significance level, whether a behaviour important to be conducted or not (evaluation of important).

\section{Subjective Norms}

Subjective norm is related to perception or someone's point of view towards others beliefs that potentially influence someone's intention to conduct or avoid certain behaviour (Hartono, 2008). This variable is derived from Putra and Basuki (2015). and being measured by using two indicators. First indicator is related to normative belief's assessment (normative belief). While the second indicator related to motivation assessment to comply (motivation of comply) towards expectation of surrounding people.

\section{Perceived Behavioural Control}

Perceived behavioural control is a perception in terms of easiness of difficulties to carry out a behaviour (Ajzen, 1991). This variable is derived from Putra dan Basuki (2015) and being measured by using two indicators. First indicator is related to belief's assessment towards the ability to control (control belief). While the second indicator is related to perception's assessment on authority to conduct behaviour (perceived power).

\section{Tax Compliance}

Tax compliance is a condition where all Taxpayers comply to fulfill all taxation obligation and performing taxation rights. This variable is derived from Muharani (2015) and being measured by using four indicators, which are calculating and paying the tax as regulated, fulfilling the SPT correctly and punctually, no tax instalment and never been sentenced in crime.

\section{Data Analysis Technique}

Regression analysis is employed to predict the influence more than one independent variables towards one dependent variables, partially or simultaneously. Based on previous theory and its explanation, it could be determined the regression equation, as follows:

$\mathrm{Y}=\mathrm{a}+\beta 1 \mathrm{X} 1+\beta 2 \mathrm{X} 2+\beta 3 \mathrm{X} 3+\mathrm{e}$

Constants:

$\mathrm{Y} \quad=$ Taxpayer compliance

a $=$ Constant

$\mathrm{X} 1=$ Attitude

$\mathrm{X} 2=$ Subjective Norm

$\mathrm{X} 3=$ Perceived Behavioural Control

$\beta 1 \ldots \beta \mathrm{n}=$ Coefficient of regression direction 


\section{Data Analysis Result and Discussion}

\section{Validity Test}

Validity test is conducted by identifying the correlation of question items with total of variable score. Question item is stated valid if $\mathrm{r}$ result $>\mathrm{r}$ table on the significance level (one side) of $5 \%$ (Santoso, 2000). The determination of $\mathrm{r}$ table score could be originated from $\mathrm{df}=$ number of cases -2 (Santoso, 2000), In this case, df value could be resulted from df $=97-2=95$ with significance level (one side) as $5 \%$. It was obtained the value of 0,1680 . While, $r$ table could be notified from the column of Corrected Item - Total Correlation.

Based on Table 1, it could be seen that entire question items in the research variable have Correlated Item - Total Correlation value above $r$ table $(0,1680)$. This indicates that that $r$ result $>r$ table, therefore, it could be concluded that all question items in the variable are considered as valid.

Table 1. Result of Validity Test

\begin{tabular}{cccc}
\hline \multirow{2}{*}{ Item Variable } & $\begin{array}{c}\text { Corrected Item- } \\
\text { Total Correlation }\end{array}$ & Item Variable & $\begin{array}{c}\text { Corrected Item- } \\
\text { Total Correlation }\end{array}$ \\
\cline { 2 - 4 } X1.1.1 & 0.724 & $\mathrm{X} 3.1 .1$ & 0.582 \\
X1.1.2 & 0.751 & $\mathrm{X} 3.1 .2$ & 0.664 \\
X1.1.3 & 0.77 & $\mathrm{X} 3.1 .3$ & 0.737 \\
X1.1.4 & 0.725 & $\mathrm{X} 3.1 .4$ & 0.555 \\
X1.2.1 & 0.736 & $\mathrm{X} 3.2 .1$ & 0.769 \\
X1.2.2 & 0.814 & $\mathrm{X} 3.2 .2$ & 0.789 \\
X1.2.3 & 0.759 & $\mathrm{X} 3.2 .3$ & 0.74 \\
X1.2.4 & 0.691 & $\mathrm{X} 3.2 .4$ & 0.67 \\
X2.1.1 & 0.611 & $\mathrm{Y} 1.1$ & 0.518 \\
X2.1.2 & 0.795 & $\mathrm{Y} 1.2$ & 0.571 \\
X2.1.3 & 0.747 & $\mathrm{Y} 1.3$ & 0.591 \\
X2.1.4 & 0.749 & $\mathrm{Y} 1.4$ & 0.596 \\
X2.2.1 & 0.568 & $\mathrm{Y} 1.5$ & 0.63 \\
X2.2.2 & 0.793 & $\mathrm{Y} 1.6$ & 0.557 \\
X2.2.3 & 0.765 & $\mathrm{Y} 1.7$ & 0.414 \\
X2.2.4 & 0.764 & & \\
\hline
\end{tabular}

\section{Reliability Test}

Reliability test could be conducted by identifying Cronbach Alpha value. A construct or variable is stated as reliable if the value of Cronbach Alpha $\geq 0,60$ (Ghozali, 2011). Based on Table 2, it can be seen that entire variables in this research have the value of Cronbach Alpha above $\geq 0,60$, it indicates that all instruments in this research is reliable.

Table 2. Result of Reliability Test

\begin{tabular}{lc}
\hline \multicolumn{1}{c}{ Variable } & Cronbach Alpha \\
\hline Attitude towards Behaviour (X1) & 0,923 \\
Subjective Norms (X2) & 0,917 \\
Perceived Behavioural Control (X3) & 0,900 \\
Intention to Perform Complaints (Y) & 0,812 \\
\hline
\end{tabular}




\section{Multicollinearity Test}

Proper regression model should present no correlation among independent variable. Multicollinearity of a model could be identified from the tolerance value and Variance Inflation Factor (VIF). Ghozal (2011) stated that if the value of Variance Inflation Factor (VIF) not more than 10 and value of tolerance not less than 0,1 then the modal considered as free from multicollinearity. While Sekaran and Bougie (2013) explained that a regression model is said free than multicollinearity if VIF value is under 10 and tolerance value is above 0,2 . Based on Table 3 , it is shown that all independent variables in this research have VIF value below 10 and tolerance value not less than 0,1 or above 0,2 . This indicates that in the regression model, no existence of correlation among independent variables or no multicollinearity involved.

Table 3. Multicollinearity Test

\begin{tabular}{llrr}
\hline & \multicolumn{3}{c}{ Collinearity Statistics } \\
Model & & Tolerance & VIF \\
\hline 1 & (Constant) & & \\
& X1 & .611 & 1.638 \\
& X2 & .586 & 1.705 \\
& X3 & .879 & 1.137 \\
\hline
\end{tabular}

\section{Heteroscedasticity Test}

Heteroscedasticity could be spotted in the graph of scatterplot. If the graph form regular pattern (wavy, wider and narrowed down), it indicated heteroscedasticity. On the contrary, if the graph forms scattered pattern it indicates the absence of heteroscedasticity (Putra \& Basuki, 2015). Figure 3 demonstrated that the nodes tend to scatter, hence it could be concluded as the absence of heteroscedasticity.

\section{Normality Test}

Proper regression model indicated by having normal distribution or close to normal. If P-P Plot performs scattered data around diagonal line, it can be concluded that the data are normal distributed. On the contrary, if the data are scattered away from diagonal line and/or unfollow the direction of normal line, hence regression normal is not normal (Putra \& Basuki, 2015). Figure 4 indicates that the data are normal distributed as they are considered as appropriate and meet the requirement as explained before.

Scatterplot

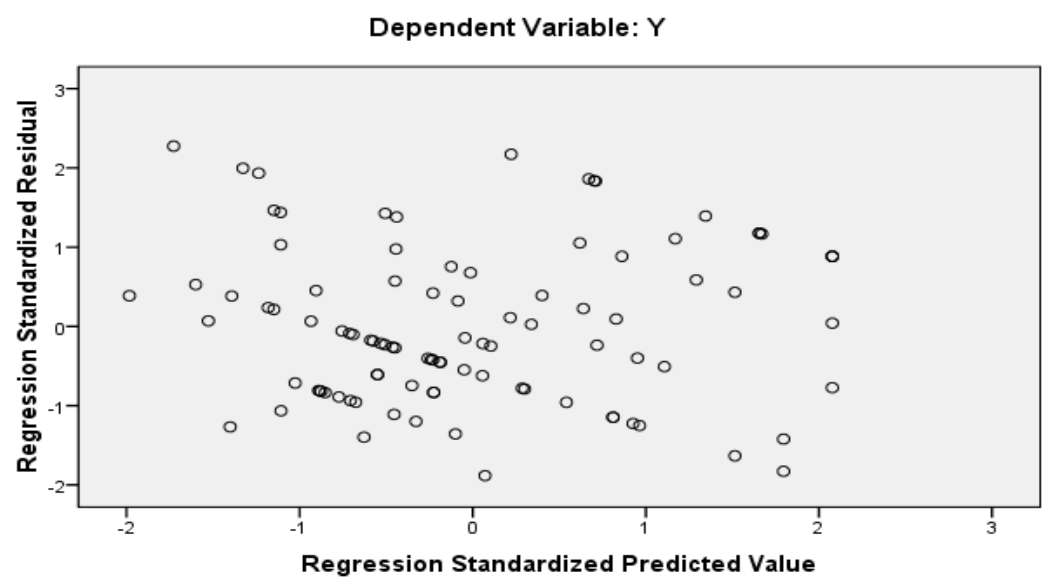

Figure 3. The Result of Heteroscedasticity Test 


\section{Normal P-P Plot of Regression Standardized Residual}

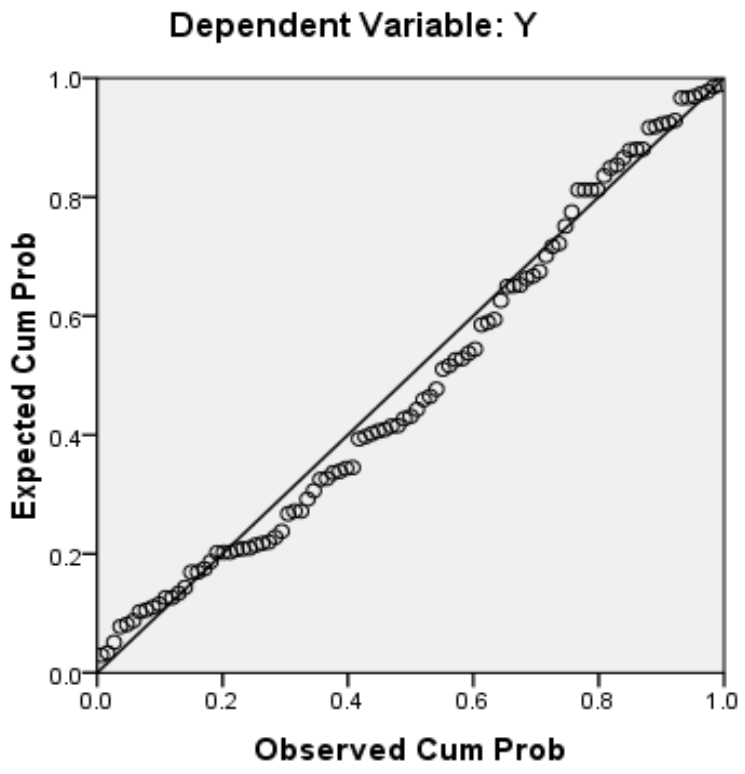

Figure 4. Normality Test Result

\section{Regression Results}

Variables involved in this research are attitude, subjective norms and perceived behavioural control. Furthermore, the collected data processed by using analysis tool (SPSS 16). The multiple regression results are presented in Table 4.

Table 4. Regression Test Results

\begin{tabular}{|c|c|c|c|}
\hline Variable & Beta & t-test & P-Value \\
\hline Constanta & 1,767 & 7,996 & 0,000 \\
\hline Attitude (X1) & 0,116 & 1,509 & 0,135 \\
\hline Subjective Norm (X2) & 0,232 & 3,021 & 0,003 \\
\hline Perceived Behavioural Control (X3) & 0,134 & 2,547 & 0,013 \\
\hline $\mathrm{R}$ & \multicolumn{2}{|c|}{0,576} & \\
\hline R Square & \multicolumn{2}{|c|}{0,332} & \\
\hline Adjusted R Square & \multicolumn{2}{|c|}{0,310} & \\
\hline F test & \multicolumn{2}{|c|}{15,406} & \\
\hline
\end{tabular}

\section{Discussion}

Based on Table 4, it is obtained that attitude towards behaviour is not significant influenced towards the compliance behaviour of personal taxpayer of MSME. This research is inversely proportional with the research conducted by Putri (2014). Perception or attitude in compliance determination towards tax for personal taxpayer of MSME is not put as a consideration. Even though, personal taxpayer of MSME has positive attitude or perception towards paid tax, yet the Personal taxpayers for MSMEs have not received or exposed with the direct benefit of tax payment. Hence, this attitude or perception is not put as a basic consideration for taxpayer to comply the taxation rule as basically tax is employed entirely for society's welfare and other significances not only for personal purposes. Besides, taxpayers still objected if their earnings are being reduced for tax. 
On the other hand, subjective norm variable is positively influenced towards compliance behaviour of personal taxpayer of MSME. This research is in line with the research was conducted by Putri (2014). This is caused by motivation of people from surroundings, such as family or friends to comply and obey the taxation regulation. The support from people around taxpayer is quite important as they could provide good suggestion, particularly if the taxpayer is a head of family that should provide good example in complying the taxation regulation. The motivation and the support from actors of MSMEs as co-workers or business partner could influence one's compliance in paying the tax. It is caused by the similar character and the way of thinking to make business partner to become reference or role model if it is related to tax. Therefore, surrounding people's influence could be used as basic of tax compliance.

Furthermore, perceived behavioural control is positively influenced towards compliance behaviour of personal taxpayer of MSME. This research is in line with the research was conducted by Putri (2014). It is caused by the considerations from taxpayer on certain issues regarding to tax. For instance, the process of calculation, reporting, and complicated payment process that leads to reluctancy for tax compliance since all above processes are considered to waste their valuable time that prefers to be dedicated for business. The substitution from official assessment system to selfassessment system worries taxpayers for incorrect calculation or inappropriate with existing taxation regulation that potentially leads to extra payment. Bad services also emerged as a certain consideration, but above all the strongest issue that influence the taxpayer is the indication of corruption or misused for all payments will be assumed as useless. these issues make the taxpayer to be reluctant due to possible difficulties or difficulties.

\section{Conclusion}

Based on previous hypothesis and explanation, a conclusion could be withdrawn. An attitude towards behaviour is not positively influenced towards behaviour compliance on personal taxpayer of MSMEs. It was proven with the result of $\mathrm{p}$ value that is bigger than the significance level of $5 \%$ as determined previously. While subjective norms and perceived behavioural control are positively influenced towards behaviour compliance of personal taxpayer of MSMEs. It was proven with $\mathrm{p}$ value that smaller than significance level of $5 \%$ as determined previously. Besides, attitude variable towards behaviour, subjective norms and perceived behavioural control simultaneously has significant influence towards the compliance of personal taxpayer of MSMEs.

This research has several limitations, for instance, the questionnaires have distributed to respondents cannot be all collected due to respondents' business and it leads to lost questionnaires for certain sectors of MSMEs. Besides, selected respondents from several sectors of MSMEs have hesitancy to become one of the respondents by considering for their tax history will be revealed. Therefore, it takes longer time to gather other replacement respondents.

The result of this research is beneficial to complete taxation literatures that influence compliance behaviour of taxpayer in Indonesia. This research also could be employed as suggestion or consideration materials for practitioners or government in this term, General Directorate of Tax to predict compliance behaviour of taxpayer in Indonesia as well as to initiate the regulation or programs that functioned to escalate the compliance of taxpayer. Therefore, the Indonesian revenue from tax could be enhanced maximally.

\section{References}

Ajzen, I. (1991). The theory of planned behaviour. Organizational Behaviour and Human Decision Processes, 50(2), 179-211.

Berita Satu. (2018). Tantangan UMKM di tahun politik. Beritasatu.Com. Retrieved from https://www.beritasatu.com/investor/473885/tantangan-umkm-di-tahun-politik 
Bobek, D., Hageman, A., \& Kelliher, C. (2013). Analyzing the role of social norms in tax compliance behaviour. Journal of Business Ethics, 115(3), 451-468.

Budiningrum, E. W. (2014). Pengaruh norma-norma sosial terbadap perilaku kepatuhan pajak usaha mikro, kecil, dan menengah (UMKM). Universitas Gadjah Mada.

Burhanudin. (2015). Theory of planned behaviour pada mahasiswa berwirausaha. Jurnal Efektif, 6(1), 60-72.

CNN Indonesia. (2016). Kontribusi UMKM terhadap PDB tembus lebih dari 60 persen. CNN Indonesia. Retrieved from https://www.cnnindonesia.com/ekonomi/20161121122525-92174080/kontribusi-umkm-terhadap-pdb-tembus-lebih-dari-60-persen

detikFinance. (2017). Sudah 9 tahun setoran pajak RI tak pernah capai target. Detik.Com. Retrieved from https:// finance.detik.com/berita-ekonomi-bisnis/d-3728111/sudah-9-tahunsetoran-pajak-ri-tak-pernah-capai-target

Ghozali, I. (2011). Analisis multivariat dengan menggunakan SPSS (edisi 3). Semarang: Badan Penerbit Universitas Diponegoro.

Hartono, J. (2008). Sistem informasi keperilakuan (2nd ed.). Yogyakarta: Andi Publisher.

Machrus, H., \& Purwono, U. (2010). Pengkuran perilaku berdasarkan theory of planned behaviour. INSAN, 12(1), 64-72.

Muharani, N. (2015). Pengaruh faktor-faktor eksternal dan internal terhadap kepatuhan wajib pajak orang pribadi. Universitas Gadjah Mada.

Park, H., \& Blenkinsopp, J. (2009). Whistleblowing as planned behaviour - a survey of South Korean police officers. Journal of Business Ethics, 85(4), 545-556. https://doi.org/10.1007/s10551-008-9788-y

Putra, A. F., \& Maharani, Y. (2018). Niat melakukan whistleblowing: persepsi mahasiswa diploma III ekonomi. Jurnal Akuntansi Indonesia, 7(2), 1-11.

Putra, A. F. (2017). Pengaruh etika, sanksi pajak, modernisasi sistem, dan transparansi pajak terhadap kepatuhan pajak. Jurnal Akuntansi Indonesia, 6(1), 1-12.

Putra, A. F., \& Basuki, H. (2015). Pengaruh faktor individual dan situasional terhadap niat melakukan whistleblowing. Accounting and Bussiness Information System Journal, 12(1), 1-10.

Putri, L. Y. (2014). Pengarub sikap, norma subjektif, dan kontrol keperilakuan yang persepsian terhadap kepatuhan wajib pajak orang pribadi di kota Yogyakarta. Universitas Negeri Yogyakarta.

Rustiyaningsih, S. (2012). Faktor-faktor yang mempengaruhi kepatuhan wajib pajak. Widya Warta, 35(2), 44-54.

Santoso, S. (2000). Buku latihan SPSS: statistik parametrik. Jakarta: PT Elex Media Komputindo.

Sekaran, U., \& Bougie, R. (2013). Research methods for business (6th ed.). New York: John Wiley \& Sons.

Siahaan, F. O. P. (2013). The effect of tax transparency and trust on taxpayers' voluntary compliance. GSTF Journal on Business Review, 2(3), 4-8.

Winardi, R. D. (2013). The influence of individual and situational factors on lower-lavel civil servants' whislteblowing intention in Indonesia. Journal of Indonesian Economy and Business, 28(3), $361-376$.

Yanah. (2013). The impact of administrative sanction and understanding of income tax law on corporate taxpayer's compliance. The International Journal of Social Sciences, 2(1), 55-75. 